UDC 336.764

JEL Classification: G21 C43 E51

http://doi.org/10.21272/mmi.2019.2-06

Svitlana Andros,

D.Sc., Associate Professor, National Science Center «Institute of Agrarian Economics», Ukraine

Larisa Novak-Kalyayeva,

D.Sc., National Academy for Public Administration under the President of Ukraine, Ukraine

Volodymyr Tykhenko,

Ph.D., Sumy State University, Ukraine

\title{
MARKETING AND MANAGEMENT OF CREDIT PORTFOLIO OF A COMMERCIAL BANK: DATA OF ECONOMIC AND STATISTICAL ANALYSIS OF BASIC PARAMETERS OF CREDIT
}

Abstract. The article analyses the loan portfolio of the bank on the main parameters of the loan: amounts, terms, interest rates. The purpose of the article is to identify the specifics of bank marketing and to develop a methodical approach to the effective management of the credit portfolio of a commercial bank using economic and statistical analysis of the main parameters of the loan. Analysis of literary sources shows that not enough attention is paid to the integrated application of marketing methods and the formation of an optimal bank loan portfolio. The relevance of the article is the need to use the mathematical apparatus to optimize the lending process. This allows you to solve questions about raising the maximum loan amounts, reducing interest rates, ensuring the timeliness of loan repayment. The methods of marketing in the grocery analysis of the credit market are considered. Analysed consumer behaviour in the market of credit products. Formulated factors affecting the size of the interest payments of the bank. The impact of each category of borrowers on the overall increase in interest payments is determined. Analysed the dynamics of debts on loans in the bank and suggested ways to solve this problem using marketing. Formulated factors affecting the size of the interest payments of the bank. The impact of each category of borrowers on the overall increase in interest payments is determined. Analysed the dynamics of debts on loans in the bank and suggested ways to solve this problem using marketing. The authors propose to use a set of economic indicators to assess the effectiveness of the loan portfolio. The proposed improved methodology for the formation of an optimal loan portfolio of the bank. The article substantiates that the rate of loan turnover and the terms for using a loan are very different in types of loans. The article uses the methods of regression analysis, probability theory, economic and mathematical statistics. The study period is 2016-2017. The study confirms that with an equal degree of risk, banks prefer a loan product with a higher yield, that is, loans extended to legal entities. The results of economic indicators allow bank managers to evaluate the estimated bank ratios used when finding the maximum loan amount. Based on this analysis, the bank's management can assess the credit market conditions, make reasoned strategic decisions and reduce credit risks.

Keywords: analysis, amount, bank, efficiency, interest rate, loan, loan portfolio, marketing, product, term.

Introduction. Today, each person, one way or another, is associated with banking services and marketing of credit products. Some pay for utilities, Internet, mobile communications, education at the bank, other people turns to the bank for a loan. In terms of the number of loans issued in recent years has increased significantly. However, not all borrowers repay loans in full. This is one of the main problems of forming an effective loan portfolio of a bank. The structure and quality of the loan portfolio of the bank largely determine the stability, reliability, image, therefore, the effectiveness of banking in general. Issues related to the effective management of the loan portfolio in the market, especially in the present, require a deep economic and statistical analysis.

Literature Review. Analysis of the literature shows that the work of scientists focuses on measuring the concentration of risk in loan portfolios (Belas et al., 2014; Behr and Guettler, 2007; Bessis, 2010; Boyd and De Nicolo, 2005; Duellmann, 2008; Christodoulakis and Satchell, 2008), the role of innovation in risk management (Barriga and Rosengren, 2004; Akhavein et al., 2005), theoretical aspects of the development of marketing (Gerasymchuk, 2014) and management (Ogubazghi and Muturi, 2014). Scientists are not paying enough attention to the complex application of marketing methods in banking and analysing the quality of a bank's loan portfolio while limiting free credit resources, their cost, interest rates

Cite as: Andros, S., Novak-Kalyayeva, L. M., \& Tykhenko., V. (2019). Marketing and Management of Credit Portfolio of a Commercial Bank: Data of Economic and Statistical Analysis of Basic Parameters of Credit. Marketing and Management of Innovations, 2, 62-73. http://doi.org/10.21272/mmi.2019.2-06 
and the timing of the use of credit resources. Previously unresolved issues that are part of a common problem. In Ukraine, there are no legal restrictions on the maximum loan rate. However, such restrictions are in the interests of clients, since a significant part of the population has a low income. The high level of interest rates makes it unprofitable to use loans of the vast majority of potential customers (Corvoisier and Gropp, 2001; Morgan and Ashcraft, 2003). Low financial literacy of the population and their desire to break out of the limits of the available minimum consumption lead to the fact that they often take risky loans, and as a result, their financial situation deteriorates significantly (Nyamboga et al., 2014). Banks that seek to win their market share sometimes issue express loans without analysing and assessing the borrower's financial reliability (Greuning and Bratanovic, 2009). Borrowers, receiving a loan, sometimes do not match their desires with the opportunities they have; as a result, the loan payments to borrowers stop (Beck et al., 2006). Thus, the number of loan arrears is growing; the quality of the loan portfolio is deteriorating. In this regard, there is a need to use the mathematical apparatus, which allows you to improve the lending process with the aim of increasing the efficiency of the bank, and in the interests of the borrower to address the issues of increasing the maximum loan amounts, reducing interest rates, ensuring timely repayment of the loan.

The purpose of the paper is to identify the specifics of bank marketing and to develop a methodical approach to the effective management of the credit portfolio of a commercial bank using economic and statistical analysis of the main parameters of the loan.

Results. Banking marketing can be formulated as the search for the most profitable (existing and future) markets for banking products, taking into account the real needs of customers. The bank, unlike the manufacturer of traditional goods, does not have the ability to build advertising on emphasizing consumer properties and the uniqueness of the resource provided to them, but must develop and promote a credit product directly. Promotion of a loan product occurs through its characteristics: maximum loan amount, interest rate, commission, loan term, repayment procedure (Pastor and Serrano, 2005). When promoting a loan product, the bank takes into account the quality of customer service: the time for consideration of the loan application, the number of required documents, etc. The advantages that the customer will receive thanks to the money given to him are particularly noted. With all the seeming innocence, this method of product promotion carries a danger, because it creates the illusion of customers that they can afford the goods and the lifestyle for which they currently have no money (Cernohorska, 2015). We believe that the borrower should be clearly aware of the obligations and responsibilities for nonfulfilment undertaken by him before the bank, as well as the impact of the loan debt on his financial and social well-being. The most appropriate in relation to the consumer is a way to promote the loan, which reveals the characteristics of the loan product and the quality of banking services, and not for the pleasure that the buyer receives by spending the borrowed money (Armeanu et al., 2015). In the credit sector, one of the complex indicators is the amount of interest on the loan. This indicator is a product of three simple indicators: the loan amount, the loan term (expressed in fractions of a year) and the loan interest rate in the form of a coefficient. The interest rate on the loan is the product of the interest rate on an annualized basis and the number of revolutions of the loan for the year (Morgan and Ashcraft, 2003). The loan to the borrower gives the financial institution, which has the right to lend in Ukraine. One of these institutions is Credit Agricole Bank. Let us analyze the loan portfolio of Credit Agricole Bank in terms of the main parameters of the loan: amounts, terms, interest rates (Bikker and Bos, 2008). The information base for the analysis is the data of the annual financial statements of Credit Agricole Bank (Annual Financial Statements of «Credit Agricole Bank», 2017). The formula for interest payments is:

$$
R=(C \times T \times P) /(360 \times 100)
$$

where $\mathrm{C}$ is the loan amount, million UAH; $\mathrm{T}$ - loan period, days; $\mathrm{P}$ - loan interest rate, \%; 360 is the number of days that make up the fiscal year. 
Convert formula 1 :

$$
R=C \times T \times P
$$

where $\mathrm{C}$ is the loan amount, million $\mathrm{UAH} ; \mathrm{T}$ is the loan term, infractions of the fiscal year, that is $(\mathrm{T} / 360)$; $P$ is the interest rate on the loan, presented as a coefficient $(P / 100)$.

Using formula 2, it is possible to determine the index of change in interest payments $\left(I_{R}\right)$ :

$$
I_{R}=\sum \frac{C_{1} T_{1} P_{1}}{C_{0} T_{0} P_{0}} \times Y_{R i}
$$

where $C_{0}$ and $C_{1}$ is the loan amount in the base and reporting period, million UAH; $T_{0}$ and $T_{1}-$ loan period in the base and reporting period, in shares of the year; $P_{0}$ and $P_{1}-$ loan interest rate, in ratios; $Y_{R i}$ is the specific weight of each element $\left(C_{1} T_{1} P_{1} / C_{0} T_{0} P_{0}\right)$ in the sum $\left(C_{1} T_{1} P_{1} / C_{0} T_{0} P_{0}\right)$.

Formula 3 allows you to compare the interest payments of the reporting period with the base period and to identify the influence of three factors: the amount, terms of use of loans and the size of interest rates (Dermine, 2009). The findings of the credit portfolio analysis of Credit Agricole Bank was presented in Table 1. Calculate the interest payments on loans granted and for the years of the period using formulas 1 or 2 . The data in Table 2.

Table 1. Credit portfolio of Credit Agricole Bank, 2016-2017, million UAH

\begin{tabular}{|c|c|c|c|c|c|c|}
\hline Type of loan & \multicolumn{4}{|c|}{2016} & \multicolumn{4}{|c|}{2017} \\
\cline { 2 - 7 } & $\begin{array}{c}\text { The loan } \\
\text { amount at the } \\
\text { end of the year, } \\
\text { million UAH }\end{array}$ & $\begin{array}{c}\text { Loan term, days } \\
\text { (share of fiscal } \\
\text { year, } \% \\
\text { (conditional) }\end{array}$ & $\begin{array}{c}\text { Interest } \\
\text { rate, \% } \\
\text { (coefficie } \\
\text { nt) }\end{array}$ & $\begin{array}{c}\text { The loan } \\
\text { amount at the } \\
\text { end of the year, } \\
\text { million UAH }\end{array}$ & $\begin{array}{c}\text { Loan term, days } \\
\text { (share of fiscal } \\
\text { year, \% } \\
\text { (conditional) }\end{array}$ & $\begin{array}{c}\text { Interest } \\
\text { rate, \% } \\
\text { (coeffic } \\
\text { ient) }\end{array}$ \\
\hline $\begin{array}{c}\text { Loans to legal } \\
\text { entities }\end{array}$ & 16851,269 & $\begin{array}{c}120 \\
(0,33)\end{array}$ & $\begin{array}{c}16,0 \\
(0,16)\end{array}$ & 18277,448 & $\begin{array}{c}180 \\
(0,5)\end{array}$ & $\begin{array}{c}15,0 \\
(0,15)\end{array}$ \\
\hline $\begin{array}{c}\text { Mortgage loans } \\
\text { to individuals }\end{array}$ & 232,322 & $\begin{array}{c}240 \\
(0,67)\end{array}$ & $\begin{array}{c}20,0 \\
(0,20)\end{array}$ & 91,312 & $\begin{array}{c}300 \\
(0,83)\end{array}$ & $\begin{array}{c}17,5 \\
(0,175)\end{array}$ \\
\hline $\begin{array}{c}\text { Consumer } \\
\text { loans to } \\
\text { individuals }\end{array}$ & 1957,424 & $\begin{array}{c}60 \\
(0,17)\end{array}$ & $\begin{array}{c}19,0 \\
(0,19)\end{array}$ & 3070,749 & 80 & $\begin{array}{c}18,0 \\
(0,22)\end{array}$ \\
\hline $\begin{array}{c}\text { Total loan } \\
\text { portfolio }\end{array}$ & $19 \mathbf{0 4 1 , 0 1 5}$ & - & - & $\mathbf{2 1 4 3 9 , 5 0 9}$ & - & - \\
\hline
\end{tabular}

Sources: calculated by the authors.

Using the data in Table 1, the index of the change in interest payments in 2017 was calculated:

$I_{R}=\left[\left(18277,448^{*} 0,5^{*} 0,15\right) /\left(16851,269^{*} 0,33^{*} 0,16\right)^{*} Y_{R 1}+\left(91,312^{*} 0,83^{*} 0,175\right) /\left(232,322^{*} 0,67^{*} 0,2\right)^{*} Y_{R 2}+\right.$ $\left.\left(3070,749^{*} 0,22^{*} 0,18\right) /\left(1957,424^{*} 0,17^{*} 0,19\right)^{*} Y_{R 3}\right]=(1370808,6 / 889747,003)^{*} Y_{R 1}+(13263,068 / 31131,148)$ ${ }^{*} Y_{R 2}+(121601,66 / 63224,795){ }^{*} Y_{R 3}=1,54{ }^{*} Y_{R 1}+0,426{ }^{*} Y_{R 2}+1,92 * Y_{R 3}=1,54{ }^{*} 0,396+0,426 * 0,1096+1,92 * 0,494$ $=0,609+0,0466+0,948=1,6$.

The results of the analysis showed that the interest payments on loans in 2017 increased compared to 2016 by 1.6 times. Interest rates decreased slightly. 
S. Andros, L. Novak-Kalyayeva, V. Tykhenko. Marketing and Management of Credit Portfolio of a Commercial Bank: Data of Economic and Statistical Analysis of Basic Parameters of Credit

Table 2. Interest payments on loans to Credit Agricole Bank, 2016-2017, million UAH

\begin{tabular}{|l|c|c|c|}
\hline \multicolumn{1}{|c|}{ Type of loan } & $\mathbf{2 0 1 6}$ & $\mathbf{2 0 1 7}$ & $\begin{array}{c}\text { Interest } \\
\text { payments, } \\
\text { million UAH }\end{array}$ \\
\cline { 2 - 3 } & $\begin{array}{c}\text { The amount of interest, } \\
\text { million UAH }\end{array}$ & $\begin{array}{c}\text { The amount of interest, } \\
\text { million UAH }\end{array}$ & $+481061,6$ \\
\hline Loans to legal entities & 889747,003 & 1370808,6 & $-17868,08$ \\
\hline Mortgage loans to individuals & 31131,148 & 13263,068 & $-58377,265$ \\
\hline Consumer loans to individuals & 63224,795 & 121601,66 & +586 \\
\hline Total loan portfolio & $\mathbf{9 8 4 1 0 2 , 9 4 6}$ & $\mathbf{1 5 0 5 6 7 3 , 3 2 8}$ & $\mathbf{5 2 1 5 7 0 , 7 8 5}$ \\
\hline
\end{tabular}

Sources: calculated by the authors.

The increase in interest payments provided an increase in the terms and amounts of loans to legal entities and consumer loans to individuals.

Define the impact of each category of borrowers on the overall increase in interest payments.

Loans granted to legal entities: $0.609 / 1.6=0.380$ or $38.06 \%$.

Mortgage loans to individuals: $0.0466 / 1.6=0.029$ or $2.91 \%$.

Consumer loans granted to individuals: $0.948 / 1.6=0.5925$ or $59.3 \%$.

Thus, the growth of the index of interest payments by 1.6 times was due to the increase in interest payments for UAH 521,570.6 million for most loans. The increase in interest payments on consumer loans granted to individuals made up the largest effect on the index, which amounted to $59.3 \%$ of the total, and then - on loans provided to legal entities - 38.06\%. A slight impact on the growth of interest payments made mortgage lending to individuals $-2.91 \%$.

The influence of factors on the change for payments can be calculated using the method of absolute differences (Kubanova, 2008; Muchiri et al., 2010).

Consider the calculation algorithm for a multiplicative factor model of the type:

$$
Y=a \times b \times c .
$$

Using basic and actual values for each factor index, we determine their absolute deviations (Christodoulakis and Satchell, 2008).

$$
\begin{aligned}
& \Delta a=a_{1}-a_{0}, \\
& \Delta b=b_{1}-b_{0}, \\
& \Delta c=c_{1}-c_{0} .
\end{aligned}
$$

The change in the value of the effective indicator for each of the factors we define using the following relations (Dermine, 2009):

$$
\begin{aligned}
& \Delta Y_{a}=\Delta a \times b_{0} \times c_{0}, \\
& \Delta Y_{b}=a_{1} \times \Delta b \times c_{0}, \\
& \Delta Y_{c}=a_{1} \times b_{1} \times \Delta c .
\end{aligned}
$$

In the presented ratios, the calculation is based on the sequential replacement of the base values of the factor indicators with their deviations, and then with the actual level of these indicators. Using the data in Table 1, we calculate the effect of three factors using the absolute difference method.

1. Sum issued loans:

$$
\Delta R_{C}=\sum\left(C_{1}-C_{0}\right) \times T_{0} \times P_{0} .
$$


$(18277,448-16851,269)^{*} 0,33^{*} 0,16+(91,312-232,322) * 0,67^{*} 0,20+(3070,749-1957,424)^{*} 0,17^{*} 0,19=$ $=75,302+(-18,895)+35,960=92,367$ million UAH.

2. Term of credit:

$\Delta R_{T}=\sum C_{1} \times\left(T_{1}-T_{0}\right) \times P_{0}$.

$18277,448^{*}(0,5-0,33)^{*} 0,16+91,312^{*}(0,83-0,67)^{*} 0,20+3070,749^{*}(0,22-0,17)^{*} 0,19=497,15+2,92+$ $+29,17=529,24$ million UAH.

3. Banking interest rates:

$\Delta R_{P}=\sum C_{1} \times T_{1} \times\left(P_{1}-P_{0}\right)$.

$18277,448^{*} 0,5^{*}(0,15-0,16)+91,312^{*} 0,83^{*}(0,175-0,20)+3070,749^{*} 0,22^{*}(0,18-0,19)=-91,39+(-1,89)+$ $+(-6,76)=-100,04$ million UAH.

The total influence of factors: $+92.367+529.24+(-100.04)$. Total $\Delta R=+521.57$ million UAH. Calculations show that interest payments increased due to an increase in loan terms by UAH 529.24 million, due to an increase in the amounts of loans issued by UAH 92.367 million, and due to a decrease in interest rates by UAH 100.04 million. The increase in interest payments on loans provided to legal entities was due to an increase in loan terms by 497.2 million UAH and an increase in the amounts of loans issued by 75.3 million UAH, respectively, but decreased due to a sharp decline in interest rates by 91.4 million UAH. Interest payments on mortgages increased due to an increase in lending terms by UAH 2.9 million but declined due to a decrease in the number of loans issued and a decrease in interest rates by UAH 18.9 million and UAH 1.9 million, respectively. Great impact on the reduction of interest payments on consumer loans provided to individuals (6.76 million UAH), made the level of interest rates - 19\% in 2016 compared to 18\% in 2017 (Table 1). On the whole, in the loan portfolio of Credit Agricole Bank, the increase in loan terms made the most significant impact on the growth of interest payments: only UAH 529.24 million, including loans to legal entities, 497.15 million UAH.

Insofar as $R=(C \times T \times P) /(360 \times 100)$, that $P=\left(\frac{R}{C}\right) \times\left(\frac{360}{T}\right) \times 100 \%$ then the interest rate change index (Giesecke, 2004):

$$
I_{P}=\sum \frac{\left(R_{1} / C_{1}\right) \times n_{1}}{\left(R_{0} / C_{0}\right) \times n_{0}} \times Y_{R i}
$$

where $\mathrm{R}_{0}$ and $\mathrm{R}_{1}$ - the amount of interest on the loan in the baseline and reporting period, million $\mathrm{UAH}$; $\mathrm{n}$ - is the number of credit revolutions per year (360/T); $Y_{R i}-$ is the specific weight of each element $\left(\left(R_{1} / C_{1}\right)^{*} n_{1}\right) /\left(\left(R_{0} / C_{0}\right)^{*} n_{0}\right)$ in the sum $\left(\left(R_{1} / C_{1}\right)^{*} n_{1}\right) /\left(\left(R_{0} / C_{0}\right)^{*} n_{0}\right)$.

The index of interest rate changes in 2017 using formula 10 could be calculated:

$\left((1370808,6 / 18277,448)^{*}(360 / 180) /(889747,003 / 16851,269)^{*}(360 / 120)\right)^{*} Y_{R 1}+\left((13263,068 / 91,312)^{*}\right.$ $\left.{ }^{*}(360 / 300) /(31131,148 / 232,322)^{*}(360 / 240)\right)^{*} Y_{\mathrm{R} 2}+\left((121601,66 / 3070,749)^{*}(360 / 80) /(63224,795 / 1957,424)\right.$ $\left.{ }^{*}(360 / 60)\right)^{*} Y_{R 3}=\left(75^{*} 2\right) /\left(52,799^{*} 3\right)^{*} Y_{R 1}+\left(145,25^{*} 1,2\right) /\left(134^{*} 1,5\right)^{*} Y_{R 2}+(39,599 * 4,5) /\left(32,299^{*} 6\right)^{*} Y_{R 3}=$ $=(150 / 158,397)^{*} Y_{R 1}+(174,3 / 201)^{*} Y_{R 2}+(178,1955 / 193,794)^{*} Y_{R 3}=0,9469^{*} Y_{R 1}+0,867^{*} Y_{R 2}+0,9195^{*} Y_{R 3}=$ $=0,9469^{*} 0,346+0,867^{*} 0,317+0,9195^{*} 0,336=0,3276+0,2748+0,30895=0,9114$. 

Economic and Statistical Analysis of Basic Parameters of Credit

The results of the analysis show that interest rates have decreased slightly. Internal factors (the risk of a loan, its collateral, size and maturity, etc.) have less effect on the change in the average interest rate on a loan. Credit specialists do not pay enough attention to the analysis of loan turnover (Armeanu et al., 2015; Behr and Guettler, 2007), meanwhile, the index method here can be a good tool. The information base for the analysis is the data of the annual financial statements of Credit Agricole Bank. Calculate the average balances of credit investments (Table 3) according to the formula (Kubanova, 2008):

$$
O_{\text {average }}=\frac{0,5 O_{1}+0_{2}+O_{3}+\cdots+O_{n-1}+0,5 O_{n}}{n-1}
$$

where $\mathrm{O}_{\text {average }}$ - is the average balance of loans for the period, million UAH; $\mathrm{O}_{1}, \mathrm{On}_{\text {- actual daily }}$ balances at the beginning and at the end of the period, million UAH; $\mathrm{O}_{2}, \mathrm{O}_{3}, \mathrm{O}_{n-1}-$ actual daily balances on other dates within the period, million $\mathrm{UAH} ; \mathrm{n}$ - is the number of days in the period.

Table 3. Average balances of loan debt and loan repayment by customers of Credit Agricole Bank, 2016-2017, million UAH

\begin{tabular}{|l|c|c|c|c|c|c|}
\hline \multirow{2}{*}{ Type of loan } & \multicolumn{2}{|c|}{$\begin{array}{c}\text { Average loan balance at the } \\
\text { end of the year, million UAH }\end{array}$} & \multicolumn{2}{|c|}{$\begin{array}{c}\text { Repaid loans at the end of } \\
\text { the year, million UAH }\end{array}$} & $\begin{array}{c}\text { Percentage of loans } \\
\text { repaid, \% }\end{array}$ \\
\cline { 2 - 8 } & 2016 & 2017 & 2016 & 2017 & 2016 & 2017 \\
\hline Loans to legal entities & 3290,273 & 1970,374 & 12697,118 & 16316,774 & 86,97 & 84,4 \\
\hline $\begin{array}{l}\text { Mortgage loans to } \\
\text { individuals }\end{array}$ & 151,876 & 27,281 & 75,079 & 63,117 & 0,51 & 0,33 \\
\hline $\begin{array}{l}\text { Consumer loans to } \\
\text { individuals }\end{array}$ & 93,529 & 48,693 & 1827,637 & 2939,836 & 12,5 & 15,2 \\
\hline Total loan portfolio & $\mathbf{3 5 3 5 , 6 7 8}$ & $\mathbf{2 0 4 6 , 3 4 8}$ & $\mathbf{1 4 5 9 9 , 8 3 4}$ & $\mathbf{1 9 3 1 9 , 7 2 7}$ & $\mathbf{1 0 0}$ & $\mathbf{1 0 0}$ \\
\hline
\end{tabular}

Sources: calculated by the authors.

The one-day turnover on repayment of loans $(\mathrm{S})$ as the ratio of the amounts of repaid loans $(\mathrm{K})$ to the duration of the year (Kubanova, 2008) could be calculated:

$$
S=K \div 360
$$

In 2016, the one-day turnover on repayment of loans provided to legal entities amounted to UAH 35.3 million (12,697.1/360), mortgage loans - UAH 0.21 million, and consumer loans - 5.1 million UAH, respectively. In general, the loan portfolio in 2016, one-day repayment of loans amounted to 40.6 million UAH $(14,599.8 / 360)$. In 2017 , the one-day turnover on repayment of loans provided to legal entities amounted to UAH 45.3 million, mortgage loans - UAH 0.18 million, and consumer loans - UAH 8.17 million, respectively. In general, in the loan portfolio in 2017, the one-day repayment of loans amounted to UAH 53.7 million (Table 4).

Using the data of tables 3 and 4, we define the average time of use of loans according to the formula:

$$
t=0 \div S
$$

The average loan use period in 2016: legal entities - 3290273/35269.77=93.3 days; mortgage loans - 151,876/208.55=728.2 days; consumer loans - 93529/5076,769=18.4 days. Overall, in 2016 the loan portfolio for the loan portfolio amounted to $3535,678 / 40555.09=87.2$ days and for the loan portfolio in 2017 : 2046348/53665.9=38.1 days (Table 5). 
S. Andros, L. Novak-Kalyayeva, V. Tykhenko. Marketing and Management of Credit Portfolio of a Commercial Bank: Data of Economic and Statistical Analysis of Basic Parameters of Credit

Table 4. One-day turnover in repayment of credits to Credit Agricole Bank, 2016-2017, thousand UAH

\begin{tabular}{|l|c|c|c|c|}
\hline \multirow{2}{*}{\multicolumn{1}{|c|}{ Type of loan }} & \multicolumn{2}{|c|}{$\begin{array}{c}\text { One-day turnover on loan } \\
\text { repayment, th. UAH }\end{array}$} & $\begin{array}{c}\text { Absolute deviation, th. } \\
\text { UAH }\end{array}$ & Growth rate, \% \\
\cline { 2 - 5 } & 2016 & 2017 & - & - \\
\hline Loans to legal entities & 35269,77 & 45324,4 & $+10054,6$ & 128,5 \\
\hline Mortgage loans to individuals & 208,55 & 175,33 & $-33,2$ & 84,07 \\
\hline Consumer loans to individuals & 5076,769 & 8166,2 & $+3089,4$ & 160,85 \\
\hline Total loan portfolio & $\mathbf{4 0 5 5 5 , 0 9}$ & $\mathbf{5 3 6 6 5 , 9}$ & $\mathbf{+ 1 3 1 1 0 , 8}$ & $\mathbf{1 3 2 , 3}$ \\
\hline
\end{tabular}

Sources: calculated by the authors.

Table 5. Duration of crediting Credit Agricole Bank, 2016-2017

\begin{tabular}{|l|c|c|c|c|}
\hline \multirow{2}{*}{ Type of loan } & \multicolumn{2}{|c|}{ Duration of using credits, days } & $\begin{array}{c}\text { Absolute deviation, } \\
\text { days }\end{array}$ & $\begin{array}{c}\text { Rates of growth, } \\
\%\end{array}$ \\
\cline { 2 - 5 } & 2016 & 2017 & - & - \\
\hline Loans to legal entities & 93,3 & 43,5 & $-49,8$ & 46,6 \\
\hline Mortgage loans to individuals & 728,2 & 155,6 & $-572,6$ & 21,4 \\
\hline Consumer loans to individuals & 18,4 & 5,9 & $-12,5$ & 32,1 \\
\hline Total loan portfolio & $\mathbf{8 7 , 2}$ & $\mathbf{3 8 , 1}$ & $\mathbf{- 4 9 , 1}$ & $\mathbf{4 3 , 7}$ \\
\hline
\end{tabular}

Sources: calculated by the authors.

The study showed that there is a tendency of a significant slowdown in the turnover of mortgage loans to individuals (572.6), loans to legal entities (49.8), consumer loans to individuals (12.5) under the influence of changes in the structure of debt. The data in Tables 4 and 5 show that the rate of credit turnover and the terms for using a credit vary considerably by type of credit. It is primarily about mortgage loans provided to individuals for the purchase of real estate. This type of lending is very risky. Risks are more associated with lower real estate prices, high inflation, changes in the exchange rate and high interest rates, loss or decline in borrower's income, possible loss of housing, property damage, and loss of customer performance (Andros, 2015). The data in Table 3 show that the largest share of repaid loans in the bank's portfolio is occupied by loans provided to legal entities ( $84.4 \%$ in 2017 ), and the smallest share is mortgage $(0.33 \%$ in 2017). This is because corporate lending is a very popular direction today (Pandula, 2015). Therefore, banks seek to develop a centralized system of this type of lending. Marketing such a loan is quite simple. Mortgage loans are a more complex product in the housing market. Despite the fact that there is a significant percentage of loan arrears, most of the borrowers pay loans on time. However, the existing share of credit debt remains a serious problem in the banking system (Bikker and Haaf, 2002). Banks are trying to solve the problem with debtors by publishing lists of their debts on their websites and a ban on leaving the country. Trying to improve the situation with overdue loans, banks offer their customers loan restructuring (Repkova and Stavarek, 2013). Often, banks offer some indulgence to borrowers who, on their own, try to find solutions to problems with repayment, "forgiving" them with fines and penalties (Cernohorska and Honza, 2014). In our opinion, such a step is a bank trick. Since at first a penalty is charged to the client in order to encourage him to regularly repay payments, and then the sanctions are terminated with the aim of encouraging. Thus, the bank, without losing anything, achieves its goal. Thus, overdue loans are a very serious problem in the banking system. The study showed that consumer credit constitutes a small proportion of repaid loans in repayment (12.5\% in 2016). This is due to the overvalued financial capabilities of the bank customers themselves. Banks are trying to deal with this problem as efficiently as possible, not paying attention to the fines and penalties of their clients, thereby encouraging them to pay loans on time (Bikker and Groeneveld, 2000; Fayman and He, 
2011). To solve this problem, banks should set "flexible" interest rates for borrowers who can repay a loan ahead of schedule. Thus, banks will encourage clients to repay the loan within the period specified in the contract. When promoting credit products to the market, banks must take into account the condition of creditors and their ability to service debts on time (Andros, 2015). Thus, the bank must take into account the financial condition of the borrower when determining the optimal loan terms. The duration of the use of loans in general for all subjects decreased by 49.1 days (38.1-87.2). The index of the average duration of use of a loan of variable composition:

$$
I_{t}=\vec{t}_{1} \div \vec{t}_{0}
$$

$$
\mathrm{I}_{\mathrm{t}}=38,1 / 87,2=0,4369 \text { or } 43,7 \% \text {. }
$$

The terms of using bank loans decreased by $56.3 \%$ (43.69-100). Index of the average duration of use of a loan of a permanent composition:

$$
I_{t}=\frac{\sum t_{1} S_{1}}{\sum S_{1}} \div \frac{\sum t_{0} S_{1}}{\sum S_{1}}
$$

$\mathrm{It}=38,1 /\left[\left(93,3^{*} 45324,4+728,2^{*} 175,33+18,4^{*} 8166,2\right) /(45324,4+175,33+8166,2)\right]=38,1 /$ $/(4506699,906 / 53665,93)=38,1 / 83,977=0,4537$ or $45,4 \%$.

Using formula 15, you can determine the change in the average duration of the use of credit:

$$
\Delta \vec{t}(\mathrm{t})=38,1-83,98=-45,9 \text { days. }
$$

Calculate the change in the average duration of the use of the loan due to structural changes in the one-day turnover on repayment:

$$
\Delta \vec{t}(\mathrm{str})=83,98-87,2=-3,2 \text { day. }
$$

The same percentage indicator can be determined using the structural shift index formula.

$$
I_{\mathrm{str}}=\frac{\sum t_{0} S_{0}}{\sum S_{1}} \div \frac{\sum t_{0} S_{1}}{\sum S_{0}}
$$

$$
I_{s t r}=83,98 / 87,2=0,97 \text { or } 96,3 \% \text {. }
$$

Thus, the decrease in the average duration of loan use is due to a significant decrease in the duration of the use of mortgage and corporate loans by $54.63 \%(45.37-100)$ or by 45.9 days. Structural changes caused a decrease in the average duration of loan use by $3.7 \%$ (96.3-100) or 3.23 days.

Based on the data in Table 5, we calculate the indices of the velocity of circulation of loans.

Variable composition index: $I_{n(t)}=87,2 / 38,1=2,29$, that is $228,9 \%$.

Index of permanent composition: $I_{n(t)}=83,98 / 38,1=2,2$, that is $220,4 \%$.

Structure Influence Index: $I_{s t r}=87,2 / 83,98=1,04$, that is $103,8 \%$.

From the calculations, it is clear that the turnover rate of mortgage and corporate loans increased by $128.9 \%(228.9-100)$ or by 49.1 days (87.2-38.1). The increase in the average speed is due to the change in turnover for individual customers, which amounted to $120.4 \%$ (220.4-100), or 45.9 days (83.98-38.1). 
Structural changes have a positive effect on the average velocity of credit, increasing the velocity of circulation by $3.8 \%$, or 3.2 days. Using the data of table 3 , we determine the average number of revolutions of the loan:

$$
m=K \div O
$$

In 2016, the number of turnovers on corporate loans: $12,697.1 / 3,290.3=3.9$, etc. In the whole, in the loan portfolio in 2016, the number of turnovers: $14599.8 / 3535.7=4.1$. In 2017, the number of turnovers on corporate loans: $16316.8 / 1970.4=8.3$, etc. In the whole, in the loan portfolio in 2017 , the number of turnovers: $19319.7 / 2046.3=9.4$. The results of the analysis showed an absolute increase in the turnover of loans in 2017 compared to 2016 by 5.3 turnover (9.4-4.1). This indicates a decrease in loan debt, an increase in loan repayment amounts and a decrease in the average interest rate on loans in 2016-2017 at the bank. Thus, credit portfolio management in Credit Agricole Bank is effective. Using the short-term loan turnover indicators (Cvilikas, 2010), one can assess the effectiveness of the loan portfolio management at Credit Agricole Bank. The effectiveness of the loan portfolio of a bank depends on the relative release of balances of loan amounts from turnover. The rate of acceleration of the turnover of short-term loans (is calculated as the difference between the duration of the use of loans in the reporting and base year, multiplied by the amount of one-day turnover on the repayment of loans in the reporting year:

$$
\begin{aligned}
& \vec{E}_{l}=\left(\vec{t}_{1}-\vec{t}_{0}\right) \times S_{1} \\
& \vec{E}_{l}=(38,1-87,2) * 53665,9=-2634997,2 \text { th. UAH. }
\end{aligned}
$$

The results of the analysis indicate an increase in the rate of rotation of loans. This suggests that financial resources were released from the turnover, which the bank can use to invest in other active operations to gain additional profit.

Conclusions. The analysis showed that the interest payments on loans in 2017 increased compared to 2016 by 1.6 times due to the growth of terms and amounts of corporate loans and consumer loans to individuals. There is a tendency to a significant slowdown in the mortgage loan turnover. The reduction in terms of loan use is due to the reduction in the duration of the use of mortgage loans and corporate loans by 45.9 days. Structural changes have caused a decrease in the duration of the use of credit by 3.23 days. The absolute increase in the turnover of loans in 2017 compared to 2016 by 5.3 turns indicates a decrease for debt on loans, an increase in the amount of loan repayment and a change in the average interest rate on loans. The increase in the rate of rotation of loans suggests that the released credit resources from the turnover, which the bank can attract to other active operations in order to obtain additional profit. Loan portfolio management at Credit Agricole Bank is efficient. Effectively manage the bank's loan portfolio by decentralizing bank marketing. The staff focuses solely on its operations. The staff offers customers exclusively loan products that belong to the relevant department. The transfer of some marketing functions to various branches increases the number of clients covered and leads to staff development. It is advisable to improve the cross-selling system in the bank. By offering the client more and more complex loan products, the bank achieves maximum efficiency when cooperating with it. Studying the customer's life cycle is an important component for the bank in its marketing activities. Measures to attract and retain customers include an assessment of the «value» of a lost client, identifying attractive categories of clients. A two-tier model of effective credit portfolio management is proposed. At the first level, this model takes into account the statistical relationship between the volume of the loan portfolio and the average interest rate. At the second level, it establishes the statistical dependence of the loan portfolio on the average maximum loan amount for the relevant category of borrowers, taking into account the basic parameters of 

Economic and Statistical Analysis of Basic Parameters of Credit

the loan. The bank's loan portfolio is managed because of this model through such step-by-step actions. 1) formation of the information base for the loan portfolio; 2) the grouping of elements of the resource base of the bank according to the degree of temporary stability and the definition of the fund's loan portfolio; 3 ) formation of a matrix of loan flows for the planned period; 4) analysis of loan portfolio liquidity. The resulting model of the financial flow of the loan portfolio gives us initial information about the quality of the management of the loan portfolio at each point in time. The use of the statistical method allows taking into account the probability of occurrence of losses on loans for various categories of borrowers whose creditworthiness did not cause any concerns at the time of issuance. The proposed method of calculating the base interest rate of accommodation. The method allows you to specify the calculation of the minimum necessary expenses of the bank for placing free resources in loans. An adjustment of the interest rate for the entire period of the fiscal year. Identified and classified factors (amounts, terms of use of loans, interest rates) that affect the interest payments of a commercial bank. When testing the developed methodology with the help of statistical analysis, an assessment was made of the effectiveness of the bank's loan portfolio management. Applying the rule of domination, with the same level of income from all possible options, the bank will prefer the least risky loan product. With an equal degree of risk, the bank will prefer a credit product with a higher yield.

Author Contributions: Calculated interest payments on loans granted and by year period, S.A. The index of changes in interest payments is investigated, S.A. The impact of each category of borrowers on the overall increase in interest payments is determined, V.G. The influence of factors on the change for payments using the method of absolute differences, V.G. Calculated average balances of loan debt and timely repayment of loans by customers, S.A. The index calculated the average duration of use of credit of variable composition, S.A. The index of the average duration of the use of a loan of a permanent composition is calculated, S.A. Calculated one-day turnover on repayment of loans by borrowers, V.G. Analysed the average duration of use of loans, V.G. Calculated one-day turnover on repayment of loans by borrowers, V.G. Analysed the average duration of use of loans, V.G. Calculated change in the average duration of the use of credit due to structural changes in one-day turnover on repayment, S.A. The assessment of the efficiency of the loan portfolio management in Credit Agricole Bank was carried out, S.A. A two-tier model of effective credit portfolio management is proposed, S.A. A method for calculating the base interest rate for placing credit resources is proposed, S.A. Proposed campaigns effective management of the loan portfolio of the bank through the decentralization of bank marketing, V.G.

Funding: The article was prepared in the framework of the fundamental research work «Development of the Theoretical and Methodological Foundations of Financial and Credit Support of the Agricultural Sector of the Economy» (state registration number 0116U000063) of the National Scientific Center «Institute of Agrarian Economics».

\section{References}

Andros, S. V. (2015). Formation and Implementation of the Strategy of Credit and Investment Activity of Banks: Theory, Methodology, Practice. Monograph. Kyiv: State Higher Educational Institution «The University of Banking», 550.

Annual Financial Ctatements of «Credit Agricole Bank» 2017. (2018). Available at: https://credit-agricole.ua/storage/files/creditagricole-audit-2017-ukr.pdf (Date of appeal: 08/17/2018).

Armeanu, D., Pascal, C., Poanta, D., Doia, C. (2015). The Credit Impact on the Economic Growth. Theoretical and Applied Economics, 22 (1), 5-14.

Akhavein, J., Frame, W. S. \& White, L.J. (2005). The Diffusion of Financial Innovations: An Examination of the Adoption of Small Business Credit Scoring by Large Banking Organizations. Journal of Business, 2, 577-596.

Barriga, L. \& Rosengren, E. (2004). Innovations in Risk Management - Lessons from the Banking Industry. Technical Paper. Boston: Federal Reserve Bank of Boston, 41.

Beck, T., Demirgüç-Kunt, A., Levine, R. (2006). Bank Concentration, Competition, and Crises: First Results. In Journal of Banking \& Finance, roc. 30, c. 5, 1581-1603. 
S. Andros, L. Novak-Kalyayeva, V. Tykhenko. Marketing and Management of Credit Portfolio of a Commercial Bank: Data of Economic and Statistical Analysis of Basic Parameters of Credit

Bikker, J. \& Bos, J.W.B. (2008). Bank Performance: A Theoretical and Empirical Framework for the Analysis of Profitability, Competition and Efficiency. USA: Routledge, 176.

Bikker, J. A., Groeneveld, J. M. (2000). Competition and Concentration in the EU Banking Industry. In Kredit und Kapital, roc. 33, c. $1,62-98$.

Bikker, J. A., Haaf, K. (2002). Competition, Concentration and their Relationship: An Empirical Analysis of the Banking Industry. In Journal of Banking \& Finance, roc. 26, c. 11, 2191-2214.

Bessis, J. (2010). Risk Management in Banking. Chichester: John Wiley \& Sons, 821.

Behr, P. and Guettler, A. (2007). Credit Risk Assessment and Relationship Lending: An Empirical Analysis of German Small and Medium-Sized Enterprises. Journal of Small Business Management, 45(2), 194-213.

Belas, J., Bartos, P., Habanik, R. et al. (2014). Determinants of Credit Risk of SMEs in the Banking Sector of the Czech Republic and Slovakia. Available at: http: //economics.soc.uoc.gr/macro/docs/Year/2014/papers/paper_3_102.pdf (Date of appeal: 09/11/2018).

Boyd, J.H. \& De Nicolo, G. (2005). The Theory of Bank Risk Taking and Competition Revisited. The Journal of Finance, 60(3), 13291343.

Corvoisier, S., Gropp, R. (2001). Bank Concentration and Retails Interest Rates. Working Paper No. 72. Frankfurt am Main: European Central Bank, 50

Christodoulakis, G. \& Satchell, S. (2008). The Validity of Credit Risk Model Validation Methods. The Analytics of Risk Model Validation, ed. Christodoulakis G., Satchell S. Oxford: Elsevier, 27-44.

Cvilikas, A. (2010). The Structure of Decisions for Banking Risk Management's Economic Efficiency Assessment. Economics and management $=$ Ekonomika ir Vadyba, 15, 893-899.

Dermine, J. (2009). Bank Valuation and Value-Based Management: Deposit and Loan Pricing, Performance Evaluation, and Risk Management. USA: McGraw-Hill, 432.

Duellmann, K. (2008). Measuring Concentration Risk in Credit Portfolios. The Analytics of Risk Model Validation, ed. Christodoulakis

G., Satchell S. Oxford: Elsevier, 59-78.

Fayman, A. \& He, L.T. (2011). Prepayment Risk and Bank Performance. The Journal of Risk Finance, 12(1), 26-40.

Gerasymchuk. V.H. (2014). Concept of Social and Ethical Marketing: Consumer and Society Welfare. Marketing Aspects of Innovative Development Management: Monograph; ed. Illyashenko. S.M. Sumy: «Papyrus» Printing House Ltd., 373-392.

Giesecke, K. (2004). Credit Risk Modeling and Valuation: an Introduction. Credit Risk: Models and Management, 2, 67

Greuning, H. \& Bratanovic, S.B. (2009). Analysing Banking Risk: a Framework for Assessing Corporate Governance and Risk Management. 3-rd edition. Washington: The World Bank, $422 . \quad$ Available at: http://documents.worldbank.org/curated/en/361471468336562959/pdf/482380PUBOAnal1010FFICIALOUSE0ONLY1.pdf (Date of appeal: 08/19/2018).

Kubanova, J. (2008). Statisticke Metody pro Ekonomickou a Technickou Praxi. 3. Vydani. Bratislava: Statistics, 247.

Nyamboga, O. T., Nyamoga, B. O., Abdi, M. et al. (2014). An Assessment of Fnancial Lteracy on Loan Repayment by Small and Medium Enterprises. Finance and Accounting, 5(12), 181-192

Morgan, D. P. \& Ashcraft, A. B. (2003). Using Loan Rates to Measure and Regulate Bank Risk: Findings and an Immodest Proposal. Journal of Financial Services Research, 2/3(24), 181-200.

Muchiri, P. N., Pintelon, L., Martin, H., De Meyer, A.-M. Empirical Analysis of Maintenance Performance Measurement in Belgian Industries. International Journal of Production Research, 2010, Vol. 48, Iss. 20, 5905-5924.

Ogubazghi, S.K. and Muturi, W. (2014). The Effect of Age and Educational Level of Owner/Managers on SMMEs' Access to Bank Loan in Eritrea: Evidence from Asmara City. American. Journal of Industrial and Business Management, 4, 632-643.

Pastor, J. M. \& Serrano, L. (2005). Efficiency, Endogenous and Exogenous Credit Risk in the Banking Systems of the Euro Area. In Applied Financial Economics, 15(9), 631-649.

Pandula, G. (2015). Bank Finance for Small and Medium-Sized Enterprises in Sri Lanka: Issues and Policy Reforms. Studies in Business and Economics, 10 (2), 32-43.

Repkova, I., Stavarek, D. (2013). Relationship Between Competition and Efficiency in the Czech Banking Industry. In Acta Universitatis Agriculturae et Silviculturae Mendelianae Brunensis, roc. 61, c. 7, 2701-2707. Available at: https://acta.mendelu.cz/media/pdf/actaun 2013061072701.pdf (Date of appeal: 09/18/2018).

Cernohorska, L. (2015). Impact of Financial Crisis on the Stability Banking Sectors in the Czech Republic and Great Britain. In Procedia Economics and Finance, 26, 234-241.

Cernohorska, L., Honza, F.(2014). The Comparison of Banking Systems in the Countries of Former Yugoslavia and in the Czech Republic. In Scientific Papers of the University of Pardubice, Series D, roc. 21, c. 30, 17-28. 
S. Andros, L. Novak-Kalyayeva, V. Tykhenko. Marketing and Management of Credit Portfolio of a Commercial Bank: Data of Economic and Statistical Analysis of Basic Parameters of Credit

С. Андрос, д.е.н., доцент, Національний науковий центр «Інститут аграрної економіки» (Україна);

Л. Новак-Каляєва, д.н.держ.упр., доцент, Національна академія державного управління при Президентові України (Україна);

В. Тихенко, к.е.н., Сумський державний університет (Україна).

Маркетинг та менеджмент кредитним портфелем банку: дані економіко-статистичного аналізу основних параметрів кредиту

У статті проаналізовано кредитний порторель банку з точки зору основних параметрів кредиту: сум, термінів, процентних ставок. Мета статті полягає у виявленні специфріки банківського маркетингу та розробці методичного підходу до ефеективного управління кредитним портфрелем комериійного банку за допомогою економіко-статистичного аналізу основних параметрів кредиту. Опрацювання літературних джерел засвідчує, що недостатньо уваги приділяється комплексному застосуванню методології маркетингу та формуванню оптимального кредитного портфеля банку. Актуальність статті полягає в необхідності використання математичного апарату для оптимізації процесу кредитування, що дозволяє вирішувати питання щодо підвищення максимальних сум кредиту, зниження процентних ставок, забезпечення своєчасності погашення кредиту. Розглянуто методи маркетингу в продуктовому аналізі ринку кредитів. Досліджено споживчу поведінку на ринку кредитних продуктів за допомогою методів фракторного аналізу. Сформульовані фрактори, що впливають на розмір процентних платежів банку. Визначено вплив кожної категорії позичальників на загальне збільшення процентних платежів. Проаналізовано динаміку боргів по кредитах у банку та запропоновано шляхи вирішення даної проблеми з використанням маркетингу. Сформовано набір індикаторів для оцінки ефрективності кредитного портфеля. Запропонована методика визначення оптимального кредитного портфеля банку. Доведено, що швидкість оборотності кредиту і терміни користування кредитом значно розрізняються за видами кредитів і суб'єктах, що кредитуються банком. Розроблені підходи до оцінювання максимальної суми кредиту в залежності від графіків платежу, доходів позичальника $i$ його кредитної історії. У статті використано методи регресійного аналізу, теорії ймовірності, економіко-математичної статистики. Періодом дослідження обрано 2016-2017 роки. Дослідженням підтверджується, що при рівній мірі ризику банки віддають перевагу кредитним продуктам $з$ більшою прибутковістю, тобто кредитам, наданим юридичним особам. Отримані результати дозволяють менеджерам банку оцінити розрахункові банківські (кредитні) коефріцієнти, які використовуються при знаходженні максимальної суми кредиту. На основі отриманого аналізу, керівництво банку може оцінити кон'юнктуру ринку кредитування, прийняти аргументовані стратегічні рішення і знизити кредитні ризики.

Ключові слова: аналіз, банк, ефективність, кредит, кредитний портфель, маркетинг, продукт, процентна ставка, сума, термін.

Manuscript received: 25.01.2019.

(C) The author(s) 2019. This article is published with open access at Sumy State University. 